Elsevier Editorial System(tm) for Applied Clay Science

Manuscript Draft

Manuscript Number:

Title: Synthesis and transformation of iron-based layered double hydroxides

Article Type: Special Issue: SynthesisZhou

Keywords: LDH, Green rust, Pyroaurite, Hydrotalcite, Mössbauer spectroscopy

Corresponding Author: Pr Christian Ruby,

Corresponding Author's Institution: LCPME University of nancy

First Author: Christian ruby, $\operatorname{Pr}$

Order of Authors: Christian ruby, Pr; Christian Ruby; Sébastien Naille, Dr; Khalil Hanna; Cédric Carteret; Martine Mullet; Michel François; Muhammad Usman, phD

Abstract: Iron-based layered double hydroxides (LDHs) obey to the general chemical formula [MII(1-x)MIIIx(OH)2]x+. [(x/n) An-, m H2O]x- and contain a minimum of $50 \%$ of iron, i.e. Fell or Felll, in the cationic sheets. As LDHs contain Fell species, these are interesting minerals for several applications such as the reduction of anionic pollutants or the degradation of organic pollutants. They are mostly prepared either by coprecipitation of dissolved species or by oxidation of hydroxilated Fell species. The synthesis routes are visualised in binary and ternary massbalance diagrams. The LDH[Fell-FellI] crystals are well crystallised hexagonal plates, the size of which diminishes rapidly when divalent or trivalent cations substitute iron. The LDH[Fell-Felll-CO3] transforms into a mixture of magnetite $\mathrm{Fe} 3 \mathrm{O} 4$ and siderite $\mathrm{FeCO} 3$ in alkaline conditions, but the adsorption of silicate or phosphate anions on the lateral faces of the crystal prevents this decomposition. In oxic conditions, two mechanism of transformation are identified depending upon the kinetics: (i) fast in situ oxidation within the solid, (ii) dissolution-precipitation of the LDH that leads to the formation of ferric oxyhydroxides such as goethite $(\mathrm{FeOOH})$. 

Submitted to Applied Clay Science

Special Issue: Synthesis of Clay Minerals and Clay-based Materials.

\title{
Synthesis and transformation of iron-based layered double hydroxides
}

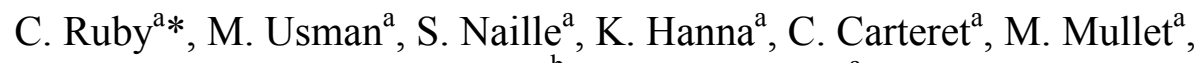 \\ M. François ${ }^{b}$, M. Abdelmoula ${ }^{a}$ \\ ${ }^{\mathrm{a}}$ Laboratoire de Chimie Physique et Microbiologie pour l'Environnement (LCPME), UMR7564 CNRS-Nancy \\ Université, 405, Rue de Vandouvre 54600 Villers-Lès-Nancy (France) \\ ${ }^{\mathrm{b}}$ Institut Jean Lamour, Département P2M, Matériaux-Métallurgie-Nanosciences-Plasmas-Surfaces \\ UMR 7198 - CNRS - Nancy-Université - UPV-Metz
}

\begin{abstract}
Iron-based layered double hydroxides (LDHs) obey to the general chemical formula $\left[\mathrm{M}_{(1-x)}^{\mathrm{II}} \mathrm{M}^{\mathrm{III}}(\mathrm{OH})_{2}\right]^{x+} \cdot\left[(x / n) A^{n-}, m \mathrm{H}_{2} \mathrm{O}\right]^{x-}$ and contain a minimum of $50 \%$ of iron, i.e. $\mathrm{Fe}^{\mathrm{II}}$ or $\mathrm{Fe}^{\mathrm{III}}$, in the cationic sheets. As $\mathrm{LDHs}$ contain $\mathrm{Fe}^{\mathrm{II}}$ species, these are interesting minerals for several applications such as the reduction of anionic pollutants or the degradation of organic pollutants. They are mostly prepared either by coprecipitation of dissolved species or by oxidation of hydroxilated $\mathrm{Fe}^{\mathrm{II}}$ species. The synthesis routes are visualised in binary and ternary mass-balance diagrams. The $\mathrm{LDH}\left[\mathrm{Fe}^{\mathrm{II}}-\mathrm{Fe}^{\mathrm{III}}\right]$ crystals are well crystallised hexagonal plates, the size of which diminishes rapidly when divalent or trivalent cations substitute iron. The $\mathrm{LDH}\left[\mathrm{Fe}^{\mathrm{II}}-\mathrm{Fe}^{\mathrm{III}}-\mathrm{CO}_{3}\right]$ transforms into a mixture of magnetite $\mathrm{Fe}_{3} \mathrm{O}_{4}$ and siderite $\mathrm{FeCO}_{3}$ in alkaline conditions, but the adsorption of silicate or phosphate anions on the lateral faces of the crystal prevents this decomposition. In oxic conditions, two mechanism of transformation are identified depending upon the kinetics: (i) fast in situ oxidation within the solid, (ii) dissolution-precipitation of the LDH that leads to the formation of ferric oxyhydroxides such as goethite $(\alpha \mathrm{FeOOH})$.
\end{abstract}

Keywords : LDH, Green rust, Pyroaurite, Hydrotalcite, Mössbauer spectroscopy *corresponding author: Christian.ruby@lcpme.cnrs-nancy.fr 


\section{Introduction}

Mixed $\mathrm{M}^{\mathrm{II}}-\mathrm{M}^{\mathrm{III}}$ layered double hydroxides (LDHs) minerals are described by the general formula $\left[\mathrm{M}^{\mathrm{II}}(1-x) \mathrm{M}_{x}^{\mathrm{III}}(\mathrm{OH})_{2}\right]^{x+} \cdot\left[(x / n) A^{n-}, m \mathrm{H}_{2} \mathrm{O}\right]^{x-}$ where $\mathrm{M}^{\mathrm{II}}$ and $\mathrm{M}^{\mathrm{III}}$ are metallic cations present in brucite-type layers $\mathrm{Mg}(\mathrm{OH})_{2}, A^{\mathrm{n}-}$ is an intercalated anion or a negatively charged molecule and $x$ is the molar fraction of the trivalent cation and also the electrostatic charge of both the brucite-type layers and the anionic interlayers. Most commonly, the values of $x$ are found in the range [0.2-0.33] (Khan and O'Hare, 2002). Recently, the researchers has shown the increasing interest for the synthesis and the characterisation of LDHs since these materials can be used for many potential applications. For example, LDHs are well known for their capacity to exchange various types of inorganic anions (Miyata, 1983; Khan and O'Hare, 2002). More recent studies have shown that LDHs can easily incorporate organic and bioorganic molecules such as ascorbic acid (Aisawa et al., 2007), urease (Vial et al., 2008), DNA (Oh et al., 2006) and even ferritin (Clemente-León et al., 2008). A particular type of LDHs which contains only iron as a cation in the brucite-type layers is called Green Rust (GR), i.e. the $\mathrm{LDH}\left[\mathrm{Fe}^{\mathrm{II}}-\mathrm{Fe}^{\mathrm{III}}\right]$. GR is an intermediate compound that forms during the $\mathrm{Fe}^{\mathrm{II}}$ species oxidation in solution (Feitknecht and Keller, 1950). For example, carbonated GR was observed as a corrosion product in water drain by Stampfl (1969). In 1996, a natural sample found in a hydromorphic soil in the forest of Fougères (Brittany, France) was identified to be homologous to green rust by using Mössbauer and Raman spectrocopies (Trolard et al. 1997). This mineral was then named fougerite (IMA 2003-057). More recently, three new occurrences were found: one in coal mine drainage sediment in South Wales (Bearcock et al., 2006) and two others in Denmark (Christiansen et al., 2009). In this last study, an X-ray diffraction pattern that corresponds to synthetic carbonated GR was presented for the first time. The properties of GR, i.e. the $\mathrm{LDH}\left[\mathrm{Fe}^{\mathrm{II}}-\mathrm{Fe}^{\mathrm{III}}\right]$, were also studied because of its ability to reduce several anionic pollutants such as nitrate (Hansen, 2001), chromate (Loyaux- 
Lawniczak et al., 2000; Bond et al., 2003; Legrand et al., 2004) and seleniate (Refait et al. 2000, 2005a; Hiroshi et al. 2009). Finally, GR was shown to promote the reduction/oxidation of an azo dye and therefore its removal from water (Kone et al., 2009) and the Fenton-like oxidation of phenol at neutral pH (Hanna et al., 2009).

In this paper, we will focus on the description of the synthesis routes and transformation of LDHs that contain a minimum of $50 \%$ of iron atoms in the brucite-like sheets, i.e. compound for which the ratio $n(\mathrm{Fe}) /\left\{n\left(\mathrm{M}^{\mathrm{II}}\right)+\mathrm{n}\left(\mathrm{M}^{\mathrm{III}}\right)\right\}$ is higher than $50 \%$. Similar to the terminology commonly used for metallic alloys, these compounds are called iron-based LDHs. Of course, the $\mathrm{LDH}\left[\mathrm{Fe}^{\mathrm{II}}-\mathrm{Fe}^{\mathrm{III}}\right]$ represent the framework of this LDHs category. The partial substitution of the $\mathrm{Fe}^{\mathrm{II}}$ or $\mathrm{Fe}^{\mathrm{III}}$ cations by other divalent or trivalent species may easily occur giving rise to ternary systems such as the $\mathrm{LDH}\left[\left\{\mathrm{Fe}^{\mathrm{II}}-\mathrm{M}^{\mathrm{II}}\right\}-\mathrm{Fe}^{\mathrm{III}}\right]$ or the $\mathrm{LDH}\left[\mathrm{Fe}^{\mathrm{II}}-\left\{\mathrm{Fe}^{\mathrm{III}}-\mathrm{M}^{\mathrm{III}}\right\}\right.$. To our knowledge, three types of partial substitutions were studied: $\mathrm{Fe}^{\mathrm{II}}$ by $\mathrm{Ni}^{\mathrm{II}}$ (Refait et al., 1993, 2005b), $\mathrm{Fe}^{\mathrm{II}}$ by $\mathrm{Mg}^{\mathrm{II}}$ (Refait et al., 2001) and more recently $\mathrm{Fe}^{\mathrm{III}}$ by $\mathrm{Al}^{\mathrm{III}}$ (Ruby et al., 2008). Fully substituted compounds that correspond to minerals such as pyroaurite $\mathrm{Mg}_{6} \mathrm{Fe}_{2}(\mathrm{OH})_{16} \mathrm{CO}_{3}, 4 \mathrm{H}_{2} \mathrm{O}$ (Allmann et al., 1968) or reevesite $\mathrm{Ni}_{18} \mathrm{Fe}_{6}(\mathrm{OH})_{48}\left(\mathrm{CO}_{3}\right)_{3}, 12 \mathrm{H}_{2} \mathrm{O}$, (De Waal and Viljoen , 1971) are not strico sensu iron-based LDHs and the synthesis of such compounds will not be considered here. By comparison with other LDHs, we will try to show specifically the iron-based LDH in terms of formation and transformation modes in both oxic and anoxic conditions.

\section{Synthesis methods and characterisation}

\subsection{Formation paths: general description}

\subsection{1. $M^{I I}-M^{I I I}$ mass balance diagram}

The formation paths of iron based LDHs can be illustrated in the mass-balance diagram presented in figure 1. Initially, this diagram was devised for interpreting $\mathrm{pH}$ titration curves obtained during the coprecipitation of $\mathrm{Fe}^{\mathrm{II}}$ and $\mathrm{Fe}^{\mathrm{III}}$ soluble species in sulphated aqueous 
medium (Ruby et al., 2003) but it can easily be generalised to any type of divalent and trivalent cations. The ordinate $R=n\left(\mathrm{OH}^{-}\right) /\left[n\left(\mathrm{M}^{\mathrm{II}}\right)+n\left(\mathrm{M}^{\mathrm{III}}\right)\right]$ represents the number of hydroxyl species per mole of iron that are consumed during the precipitation of a given compound and the abscissa $x=n\left(\mathrm{M}^{\mathrm{III}}\right) /\left[n\left(\mathrm{M}^{\mathrm{II}}\right)+n\left(\mathrm{M}^{\mathrm{III}}\right)\right]$ is the molar fraction of trivalent cations. The position of the aqueous species $\mathrm{M}_{\text {aq }}^{\mathrm{II}}, \mathrm{M}^{\mathrm{III}}$ aq and solid compounds $\mathrm{M}^{\mathrm{II}}(\mathrm{OH})_{2}$, the $\mathrm{LDH}\left[\mathrm{M}^{\mathrm{II}}-\mathrm{M}^{\mathrm{III}}\right]$, the spinel $\mathrm{M}^{\mathrm{II}} \mathrm{M}^{\mathrm{III}} \mathrm{O}_{4}$ and the oxyhydroxide $\mathrm{M}^{\mathrm{III}} \mathrm{OOH}$ are presented in Fig. 1.The synthesis of LDHs is most commonly achieved by the addition of a basic solution to a mixture of soluble species $\left\{\mathrm{M}_{\text {aq }}^{\mathrm{II}}, \mathrm{M}^{\mathrm{III}}\right.$ aq $\}$. It corresponds to the vertical path [AD] illustrated in figure 1. The major advantage of this method is that the value of $x$ of the initial solution can be adjusted accurately in order to determine the LDHs composition flexibility.

LDHs may also contain a unique metallic cation which exists in two oxidation degrees $\mathrm{M}^{\mathrm{II}}$ and $\mathrm{M}^{\mathrm{III}}$. Most of the transition metals of the $3 \mathrm{~d}$ level, i.e. Ti, V, Cr, Mn, Fe, Co and Ni, have this property. Such LDHs can potentially be prepared by a precipitation/oxidation pathway illustrated in figure 1. The synthesis is realised in two steps: (i) A basic solution is added to soluble $\mathrm{M}^{\mathrm{II}}$ species that precipitates to form either a suspension of a $\mathrm{M}^{\mathrm{II}}(\mathrm{OH})_{2}$ solid compound or a $\left\{\mathrm{M}^{\mathrm{II}}(\mathrm{OH})_{2}, \mathrm{M}^{\mathrm{II}}{ }_{\mathrm{aq}}\right\}$ mixture by following the path [BC], (ii) the divalent species are then oxidised to form the $\mathrm{LDH}\left[\mathrm{M}^{\mathrm{II}}-\mathrm{M}^{\mathrm{III}}\right]$ along the path $\mathrm{CD}$. As it will be discussed in section 2.2.2., the slope of line CD depends on the nature of the oxidant. The easiest way to do such an oxidation is to simply agitate the $\mathrm{M}^{\mathrm{II}}(\mathrm{OH})_{2}$ suspension in contact with air and to control the redox potential $E_{h}$ of the suspension in order to follow the different oxidation steps. Other oxidants such as hydrogen peroxide $\mathrm{H}_{2} \mathrm{O}_{2}$, iodine $\mathrm{I}_{2}$ or persulphate $\mathrm{S}_{2} \mathrm{O}_{8}{ }^{2-}$ can also be used, the advantage here is to know the oxidation degree of the product by controlling the amount of added oxidant. The precipitation/oxidation pathway was used for the preparation of both the LDH[Fe $\left.{ }^{\mathrm{II}}-\mathrm{Fe}^{\mathrm{III}}\right]$ (Hansen, 2001; Genin et al., 2006a) and the $\mathrm{LDH}\left[\mathrm{Co}^{\mathrm{II}}-\mathrm{Co}^{\mathrm{III}}\right]$ (Ma et al., 2008). 


\subsubsection{Formation of ternary $L D H\left[F e^{I I},\left\{F e^{I I I}, M^{I I I}\right\}\right]$ and $L D H\left[\left\{F e^{I I}, M^{I I}\right\}, F e^{I I I}\right]$}

Iron-based $\mathrm{LDHs}$, where a partial substitution of the $\mathrm{Fe}^{\mathrm{III}}$ or $\mathrm{Fe}^{\mathrm{II}}$ cations occurs, are synthesised by the same kind of pathways described for binary $\mathrm{LDH}\left[\mathrm{Fe}^{\mathrm{II}}-\mathrm{Fe}^{\mathrm{III}}\right]$, i.e. by coprecipitation or by oxidation. Such syntheses can be represented in a ternary mass-balance diagram (Fig. 2). This representation was initially proposed to study the coprecipitation of $\left[\left\{\mathrm{Fe}^{\mathrm{II}},\left\{\mathrm{Fe}^{\mathrm{III}}, \mathrm{Al}^{\mathrm{III}}\right\}\right]\right.$ mixtures in sulphated aqueous solution (Ruby et al., 2008). The diagram is an equilateral triangle and the composition of any point is easily obtained by plotting the perpendicular to the triangle sides as usually done when studying the phase diagram of ternary alloys (bottom of Fig. 2a). The number of moles of hydroxyl per mole of total cations $R=n\left(\mathrm{OH}^{-}\right) / n\left(\mathrm{M}_{\mathrm{tot}}\right)$ that is necessary to form a given compound is situated on the perpendicular to the triangle base. The formation pathways of the $\mathrm{M}^{\mathrm{III}}$ substituted LDHs are presented in figure $2 \mathrm{a}$. The domain of the ternary $\mathrm{LDH}\left[\left\{\mathrm{Fe}^{\mathrm{II}}, \mathrm{M}^{\mathrm{II}}\right\}, \mathrm{Fe}^{\mathrm{III}}\right]$ is situated in between the two segments corresponding to the $\mathrm{LDH}\left[\mathrm{Fe}^{\mathrm{II}}-\mathrm{Fe}^{\mathrm{III}}\right]$ and the $\mathrm{LDH}\left[\mathrm{Fe}^{\mathrm{II}}-\mathrm{M}^{\mathrm{III}}\right]$. On figure $2 b$, the formation pathways of $\mathrm{M}^{\mathrm{II}}$-substituted LDHs are shown. The domain of the $\operatorname{LDH}\left[\left\{\mathrm{Fe}^{\mathrm{II}}, \mathrm{M}^{\mathrm{II}}\right\} \mathrm{Fe}^{\mathrm{III}}\right]$ is situated in between the segments corresponding to the $\mathrm{LDH}\left[\mathrm{Fe}^{\mathrm{II}}-\mathrm{Fe}^{\mathrm{III}}\right]$ and the $\operatorname{LDH}\left[\left\{\mathrm{Fe}^{\mathrm{II}}, \mathrm{M}^{\mathrm{II}}\right\}, \mathrm{Fe}^{\mathrm{III}}\right]$ with $x\left(\mathrm{M}^{\mathrm{II}}\right)=0.5$. In both cases, the most trivial way to prepare such a compound is to prepare a mixture of soluble species, i.e. $\left[\left\{\mathrm{Fe}^{\mathrm{II}},\left\{\mathrm{Fe}^{\mathrm{III}}, \mathrm{M}^{\mathrm{III}}\right\}\right]\right.$ or $\left[\left\{\mathrm{Fe}^{\mathrm{II}}, \mathrm{M}^{\mathrm{II}}\right\}, \mathrm{Fe}^{\mathrm{III}}\right]$ with the desired molar fractions, and to add a basic solution at a ratio $R=n\left(\mathrm{OH}^{-}\right) / n\left(\mathrm{M}_{\text {tot }}\right)$ close to 2 . This coprecipitation syntheses route corresponds to a vertical segment that starts into the domain of the ternary LDH and is situated perpendicularly to the triangle base. The $\operatorname{LDH}\left[\left\{\mathrm{Fe}^{\mathrm{II}},\left\{\mathrm{Fe}^{\mathrm{III}}, \mathrm{M}^{\mathrm{III}}\right\}\right]\right.$ could also be obtained by a partial oxidation of an $\mathrm{LDH}\left[\mathrm{Fe}^{\mathrm{II}}-\mathrm{M}^{\mathrm{III}}\right]$ (Fig 4a), but to our knowledge such a method has not yet been tested. In sulphated medium, the coprecipitation of the LDH[Fe ${ }^{\mathrm{II}}-$ $\mathrm{Al}^{\mathrm{III}}$ ] leads unfortunately to an amorphous compound (Ruby et al., 2008) that is difficult to use as a starting product for an oxidation experiment. The oxidation path presented in figure 
2b was used to prepare the $\operatorname{LDH}\left[\left\{\mathrm{Fe}^{\mathrm{II}}, \mathrm{Ni}^{\mathrm{II}}\right\}, \mathrm{Fe}^{\mathrm{III}}\right]$ (Refait et al., 1993). In these experiments, a mixture of soluble species $\left\{\mathrm{Fe}_{\text {aq }}^{\mathrm{II}}, \mathrm{Ni}^{\mathrm{II}}\right.$ aq $\}$, i.e. point $\mathrm{A}$, is precipitated to form a mixture of $\left\{\mathrm{Fe}(\mathrm{OH})_{2}, \mathrm{Ni}(\mathrm{OH})_{2}\right\}$ in point $\mathrm{B}$. In a second step, the $\mathrm{Fe}^{\mathrm{II}}$ species are oxidised by air to form the $\operatorname{LDH}\left[\left\{\mathrm{Fe}^{\mathrm{II}}, \mathrm{Ni}^{\mathrm{II}}\right\}, \mathrm{Fe}^{\mathrm{III}}\right]$ by following the path $\mathrm{BC}$. During this oxidation reaction, the quantity of $\mathrm{Ni}^{\mathrm{II}}$ remains constant since $\mathrm{Fe}^{\mathrm{II}}$ species are much more easily oxidised by dissolved $\mathrm{O}_{2}$. A similar way of syntheses was used to prepare a fully substituted $\mathrm{LDH}\left(\mathrm{Co}^{\mathrm{II}}-\right.$ $\mathrm{Fe}^{\mathrm{III}}$ ) by oxidation of an $\mathrm{LDH}\left(\mathrm{Co}^{\mathrm{II}}-\mathrm{Fe}^{\mathrm{II}}\right)$ (Ma et al., 2007). Iodine $\mathrm{I}_{2}$ was chosen as an oxidant because the standard redox potential of the $\mathrm{I}_{2} / \mathrm{I}^{-}$couple is situated in between the $\mathrm{E}^{\mathrm{o}}$ values of the $\mathrm{Fe}^{\mathrm{II}} / \mathrm{Fe}^{\mathrm{III}}$ and $\mathrm{Co}^{\mathrm{II}} / \mathrm{Co}^{\mathrm{III}}$ couples. By this way, only the $\mathrm{Fe}^{\mathrm{II}}$ species of the $\mathrm{LDH}\left(\mathrm{Co}^{\mathrm{II}}-\mathrm{Fe}^{\mathrm{II}}\right)$ were oxidised and a pure and well crystallised $\mathrm{LDH}\left(\mathrm{Co}^{\mathrm{II}}-\mathrm{Fe}^{\mathrm{III}}\right)$ was observed.

\subsection{Synthesis of the LDH[Fe $\left.e^{I I}-F e^{I I I}\right]$ (green rust)}

\subsubsection{Coprecipitation of soluble $F e^{I I}$ and $F e^{I I I}$ species}

The coprecipitation method was used to determine the composition flexibility of the $\mathrm{LDH}\left[\mathrm{Fe}^{\mathrm{II}}-\mathrm{Fe}^{\mathrm{III}}-\mathrm{SO}_{4}\right]$ (Ruby et al. , 2003) and the $\mathrm{LDH}\left[\mathrm{Fe}^{\mathrm{II}}-\mathrm{Fe}^{\mathrm{III}}-\mathrm{CO}_{3}\right]$ (Ruby et al., 2006b). These experiments were conducted in a gas-tight reactor with continuous $\mathrm{N}_{2}$ bubbling in aqueous solution in order to avoid the oxidation of ferrous ions $\mathrm{Fe}^{\mathrm{II}}$. A systematic study of the titration of $\mathrm{Fe}^{\mathrm{II}}$ and $\mathrm{Fe}^{\mathrm{III}}$ by $\mathrm{NaOH}$ in a sulphated aqueous medium showed that only the $\mathrm{LDH}\left[\mathrm{Fe}^{\mathrm{II}}-\mathrm{Fe}^{\mathrm{III}}-\mathrm{SO}_{4}\right]$ with a unique composition $x=0.33$ was formed by this synthesis route (Ruby et al., 2003). When the coprecipitation was realised at values of $x>0.33$ or $x<0.33$,

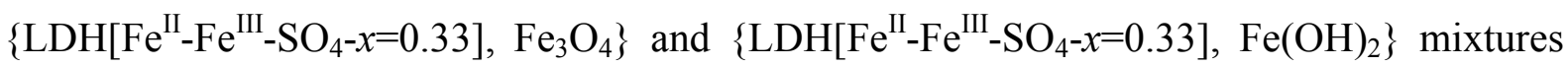
are respectively formed. Nevertheless, the formation of a $\mathrm{LDH}\left[\mathrm{Fe}^{\mathrm{II}}-\mathrm{Fe}^{\mathrm{III}}-\mathrm{SO}_{4}\right]$ with a ratio $x=0.25$ was achieved by performing an anionic exchange of a chlorinated $\mathrm{LDH}\left[\mathrm{Fe}^{\mathrm{II}}-\mathrm{Fe}^{\mathrm{III}}-\mathrm{Cl}^{-}\right]$ precipitated at the same $x$ value (Hansen et al., 2001). Some flexibility of composition was also observed for the $\mathrm{LDH}\left[\mathrm{Fe}^{\mathrm{II}}-\mathrm{Fe}^{\mathrm{III}}-\mathrm{CO}_{3}\right]$ that can be prepared in the range $x \in[\sim 0.25,0.33]$. 
For the preparation of the $\mathrm{LDH}\left[\left[\mathrm{Fe}^{\mathrm{II}}-\mathrm{Fe}^{\mathrm{III}}-\mathrm{CO}_{3}\right]\right.$ at $x=0.25$, it was necessary to prepare the initial solution by dissolving $\mathrm{FeCl}_{3}$ and $\mathrm{FeCl}_{2}$ salts followed by the addition of a $\mathrm{Na}_{2} \mathrm{CO}_{3}$ solution. Indeed, if $\mathrm{Fe}_{2}\left(\mathrm{SO}_{4}\right)_{3}$ and $\mathrm{Fe}^{\mathrm{II}} \mathrm{SO}_{4}$ salts were dissolved into the initial solution, the $\mathrm{LDH}\left[\mathrm{Fe}^{\mathrm{II}}-\mathrm{Fe}^{\mathrm{III}}-\mathrm{SO}_{4}\right]$ precipitates before the $\mathrm{LDH}\left[\mathrm{Fe}^{\mathrm{II}}-\mathrm{Fe}^{\mathrm{III}}-\mathrm{CO}_{3}\right]$ during the alkalinisation process and only the $\operatorname{LDH}[x=0.33]$ is obtained.

\subsubsection{Oxidation of $\mathrm{Fe}(\mathrm{OH})_{2}$ and $\left\{\mathrm{Fe}(\mathrm{OH})_{2}, \mathrm{Fe}^{I I}\right\}$ mixture}

Another easy way to prepare the $\mathrm{LDH}\left[\mathrm{Fe}^{\mathrm{II}}, \mathrm{Fe}^{\mathrm{III}}\right]$ is to perform an aerial oxidation of a suspension that contains $\mathrm{Fe}(\mathrm{OH})_{2}$ precipitates. In sulphated and chlorinated aqueous medium (Genin et al., 2006a), it was observed that only the suspensions that contain a specific amount of soluble $\mathrm{Fe}^{\mathrm{II}}$ species led to the formation of $100 \%$ of the LDH. For example in sulphated medium, this excess of $\mathrm{Fe}^{\mathrm{II}}{ }_{\text {aq }}$ is described by the following chemical reaction:

$$
5 \mathrm{Fe}^{\mathrm{II}}(\mathrm{OH})_{2}+\mathrm{Fe}^{2+}{ }_{\text {aq }}+\mathrm{SO}_{4}{ }^{2-}+1 / 2 \mathrm{O}_{2}+\mathrm{H}_{2} \mathrm{O} \Leftrightarrow \mathrm{Fe}_{4}{ }_{4} \mathrm{Fe}^{\mathrm{III}}{ }_{2}(\mathrm{OH})_{12} \mathrm{SO}_{4}(1)
$$

Therefore, the initial $\mathrm{Fe}^{\mathrm{II}}{ }_{\text {aq }}$ solution was partially precipitated by adding a $\mathrm{NaOH}$ solution with a ratio $r=n\left(\mathrm{OH}^{-}\right) / n\left(\mathrm{Fe}^{\mathrm{II}}\right)$ of exactly $5 / 3$. If $\mathrm{Fe}^{\mathrm{II}}$ species were precipitated with a ratio $r$ equal to 2, i.e. the pure $\mathrm{Fe}(\mathrm{OH})_{2}$ is formed without any excess of $\mathrm{Fe}^{\mathrm{II}}{ }_{\text {aq }}$, theoxidation led to the precipitation of pure magnetite. $r$ values in the range ]5/3, 2[ led to the formation of $\left\{\mathrm{LDH}\left[\mathrm{Fe}^{\mathrm{II}}-\mathrm{Fe}^{\mathrm{III}}-\mathrm{SO}_{4}\right], \mathrm{Fe}_{3} \mathrm{O}_{4}\right\}$ mixtures. Other experiments were carried out by using persulphate anions $\mathrm{S}_{2} \mathrm{O}_{8}{ }^{2-}$ as an oxidant (Ruby et al., 2006a). In this case; the oxidation of pure $\mathrm{Fe}(\mathrm{OH})_{2}$ led to the formation of $100 \%$ of $\mathrm{LDH}\left[\mathrm{Fe}^{\mathrm{II}}, \mathrm{Fe}^{\mathrm{III}}\right]$ according to the following reaction :

$$
5 \mathrm{Fe}^{\mathrm{II}}(\mathrm{OH})_{2}+\mathrm{S}_{2} \mathrm{O}_{8}{ }^{2-}+1 / 2 \mathrm{O}_{2}+\mathrm{H}_{2} \mathrm{O} \Leftrightarrow \mathrm{Fe}_{4}{ }_{4} \mathrm{Fe}^{\mathrm{III}}{ }_{2}(\mathrm{OH})_{12} \mathrm{SO}_{4}(2)
$$

By comparing the results obtained with several oxidants (Ruby et al., 2006a), a general rule was obtained that the thermodynamically favourable reactions were $\mathrm{pH}$ independent, as it is 
the case for reactions (1) and (2). If the reduction of the oxidant corresponds to the general half reaction:

$$
(\mathrm{Ox})+n \mathrm{e}^{-} \Leftrightarrow(\mathrm{Red})+v \mathrm{OH}^{-}
$$

The specific ratio $r=n\left(\mathrm{OH}^{-}\right) / n\left(\mathrm{Fe}^{\mathrm{II}}\right)$ of the initial solution that has to be chosen for preparing $100 \%$ of the $\mathrm{LDH}$ with a $\mathrm{Fe}^{\mathrm{III}}$ molar fraction $x$ is given by the general formula (Ruby et al., 2006a):

$$
r=2-(v / n) x(4)
$$

For example, for the redox couple $\mathrm{O}_{2} / \mathrm{OH}^{-}$, the half reaction is $\mathrm{O}_{2}+\mathrm{H}_{2} \mathrm{O}+2 \mathrm{e}^{-}+2 \mathrm{OH}^{-}$and $(v / n)=1$. For preparing the $\mathrm{LDH}\left[\mathrm{Fe}^{\mathrm{II}}-\mathrm{Fe}^{\mathrm{III}}\right]$ at a $x$ value of $1 / 3$, the $r$ value is therefore equal to $5 / 3$ according to equation (4) which is in good agreement with the experimental observations.

\subsubsection{Reactivity of $\mathrm{Fe}^{I I}$ species with ferric oxyhydroxides}

The $\mathrm{LDH}\left[\mathrm{Fe}^{\mathrm{II}}-\mathrm{Fe}^{\mathrm{III}}\right]$ can also be formed by controlling the reactivity of $\mathrm{Fe}^{\mathrm{II}}$ species with ferric oxyhydroxides such as lepidocrocite $\gamma$-FeOOH (Tamaura et al., 1985) or ferrihydrite (Hansen, 2001). In these experiments, soluble $\mathrm{Fe}^{\mathrm{II}}$ species were introduced into a suspension that contains the ferric oxyhydroxide at a $\mathrm{pH}$ close to 7 . This $\mathrm{pH}$ allows a sufficient hydroxylation rate of the $\mathrm{Fe}^{\mathrm{II}}$ species necessary to activate the reaction. The $\mathrm{LDH}\left[\mathrm{Fe}^{\mathrm{II}}-\mathrm{Fe}^{\mathrm{III}}-\right.$ $\left.\mathrm{SO}_{4}\right]$ can also be prepared by fixing the hydroxylation rate $R=\mathrm{n}\left(\mathrm{OH}^{-}\right) /\left[\mathrm{n}\left(\mathrm{Fe}^{\mathrm{II}}\right)+\mathrm{n}\left(\mathrm{Fe}^{\mathrm{III}}\right)\right]$ at a exact value of 7 with a basic solution such as $\mathrm{NaOH}$ (Ruby et al., 2003). This ratio corresponds to the formation of a mixture $\left\{\mathrm{FeOOH}, 2 \mathrm{Fe}(\mathrm{OH})_{2}\right\}$ that was hypothesised to be the precursor of the formation of the $\mathrm{LDH}\left[\mathrm{Fe}^{\mathrm{II}}-\mathrm{Fe}^{\mathrm{III}}-\mathrm{SO}_{4}\right]$. A heterogeneous reaction that would occur at the surface of the ferric oxyhydroxide was described by Ruby et al. (2006). 


\subsection{Characterisation of iron-based layered double hydroxides}

\subsubsection{Morphology of the crystals}

Non-substituted $\mathrm{LDH}\left[\mathrm{Fe}^{\mathrm{II}}-\mathrm{Fe}^{\mathrm{III}}\right]$ prepared at room temperature either by the coprecipitation or the oxidation experiments are constituted by well-defined hexagonal plates with a lateral size $D$ situated in the range $[100-500] \mathrm{nm}$ and a thickness $d$ of $\sim[10-50] \mathrm{nm}$ as observed by transmission electron microscopy (TEM) (Fig. 3a). The ratio $D / d$ was found to be close to 10 for the $\mathrm{LDH}\left[\mathrm{Fe}^{\mathrm{II}}-\mathrm{Fe}^{\mathrm{III}-} \mathrm{SO}_{4}{ }^{2-}\right]$ and close to 5 for the $\mathrm{LDH}\left[\mathrm{Fe}^{\mathrm{II}}-\mathrm{Fe}^{\mathrm{III}-} \mathrm{CO}_{3}{ }^{2-}\right]$ (Ruby et al., 2006b). For this reason, it was possible to see a high proportion of the $\mathrm{LDH}\left[\mathrm{Fe}^{\mathrm{II}}-\mathrm{Fe}^{\mathrm{III}-} \mathrm{CO}_{3}{ }^{2-}\right]$ crystals with their basal plane situated perpendicularly to the TEM grid (Fig 3a). Diffraction of isolated crystals along the [001] zone axis was performed and this allows us to determine the parameter $a$ of the hexagonal cell $(a \sim 3.2 \AA)$.

The substitution of the trivalent or the divalent cation by another chemical element gives rise to a rapid decrease of the crystal size as observed in Fig. 3b\&c. For example the substitution of half of the $\mathrm{Fe}^{\mathrm{III}}$ cations by $\mathrm{Al}^{\mathrm{III}}$ into the $\mathrm{LDH}\left[\mathrm{Fe}^{\mathrm{II}}-\mathrm{Fe}^{\mathrm{III}}-\mathrm{SO}_{4}\right]$ induces a decrease of the lateral crystal size of $\sim 10 \mathrm{~nm}$ (Fig. 3b). A more drastic effect is observed if the divalent $\mathrm{Fe}^{\mathrm{II}}$ species are fully substituted by $\mathrm{Ni}^{\mathrm{II}}$ (Fig. 3c). In this case the LDH consists of crystallised nanoparticles and only a thermal heating in the range $\left[100^{\circ} \mathrm{C}-180^{\circ} \mathrm{C}\right]$ allows us to obtain bigger crystals with a hexagonal shape (not shown). Note that thermal treatment in this range of temperature of iron-based $\mathrm{LDH}$ leads to a decomposition into $\left\{\mathrm{Fe}_{3} \mathrm{O}_{4}, \mathrm{Fe}(\mathrm{OH})_{2}\right\}$ or $\left\{\mathrm{Fe}_{3} \mathrm{O}_{4}\right.$, $\left.\mathrm{FeCO}_{3}\right\}$ mixture. Therefore, thermal treatment is unfortunately of no use for increasing the crystal size of iron-based LDHs. 


\subsubsection{Crystallographical structure}

The structure of the $\mathrm{LDH}\left[\mathrm{Fe}^{\mathrm{II}}-\mathrm{Fe}^{\mathrm{III}}-\mathrm{SO}_{4}\right], \mathrm{LDH}\left[\mathrm{Fe}^{\mathrm{II}}-\mathrm{Fe}^{\mathrm{III}}-\mathrm{Al}^{\mathrm{III}}-\mathrm{SO}_{4}\right]$ and $\mathrm{LDH}\left[\mathrm{Fe}^{\mathrm{II}}-\mathrm{Fe}^{\mathrm{III}}-\right.$ $\mathrm{CO}_{3}$ ] were recently investigated by high resolution X-ray diffraction experiments performed at the European Synchrotron Radiation Facility (ESRF) (Aissa et al., 2006; Ruby et al., 2008). Diffractograms of the $\mathrm{LDH}\left[\mathrm{Fe}^{\mathrm{II}}-\mathrm{Fe}^{\mathrm{III}}-\mathrm{SO}_{4}\right]$ and the $\mathrm{LDH}\left[\mathrm{Fe}^{\mathrm{II}}-\mathrm{Fe}^{\mathrm{III}}-\mathrm{CO}_{3}\right]$ are presented in figure 4. The position of the peaks shows that the two LDHs exhibit a quite different crystallographical structure that was determined with Rietveld refinements. The LDH[Fe ${ }^{\mathrm{II}}-$ $\left.\mathrm{Fe}^{\mathrm{III}}-\mathrm{SO}_{4}\right]$ crystallises in the hexagonal structure, space goup $P \overline{3} 1 \mathrm{~m}$, and the unit cell is characterised by the parameters $a=5.50683(3) \AA$ and $c=10.9664(2) \AA$; where $c$ is equal to the interlayer spacing $d$ along the [001] axis. The $\mathrm{LDH}\left[\mathrm{Fe}^{\mathrm{II}}-\mathrm{Fe}^{\mathrm{III}}-\mathrm{CO}_{3}\right]$ crystallises in the trigonal structure, space group $\mathrm{R} \overline{3} \mathrm{~m}$, and the corresponding hexagonal triple cell is characterised by the parameters $a=3.17588(2) \AA$ and $\mathrm{c}=22.7123(3) \AA$; the interlayer spacing is now $d=c / 3=7.57 \AA$. The interlayer spacing $d$ of the $\mathrm{LDH}\left[\mathrm{Fe}^{\mathrm{II}}-\mathrm{Fe}^{\mathrm{III}}-\mathrm{SO}_{4}\right]$ is larger because it contains a double layer of oriented sulphated anions and water molecules (Ruby et al., 2008). Therefore, the structure of these two LDHs can be distinguished very easily by Xray diffraction and were denominated by Bernal et al. (1954). green rust $1(\mathrm{R} \overline{\mathrm{m}} \mathrm{m})$ and green rust $2(\mathrm{P} \overline{3} 1 \mathrm{~m})$. For instance, the position of the most intense (003) peak of the $\mathrm{LDH}\left[\mathrm{Fe}^{\mathrm{II}}-\mathrm{Fe}^{\mathrm{III}}-\mathrm{CO}_{3}\right]$ is situated at a much lower angle than the (0001) peak of the $\mathrm{LDH}\left[\mathrm{Fe}^{\mathrm{II}}-\mathrm{Fe}^{\mathrm{III}}-\mathrm{SO}_{4}\right]$ simply because of the difference of interlayer spacing (Fig. 4).

\subsubsection{Speciation of iron with Mössbauer spectroscopy}

${ }^{57} \mathrm{Fe}$ Mössbauer spectroscopy is a powerful technique for determining accurately the relative proportion of $\mathrm{Fe}^{\mathrm{II}}$ and $\mathrm{Fe}^{\mathrm{III}}$ species of iron-based LDHs. It is also very useful to detect the formation of by-products that contain iron such as ferrous hydroxide $\mathrm{Fe}(\mathrm{OH})_{2}$, siderite $\mathrm{FeCO}_{3}$, magnetite $\mathrm{Fe}_{3} \mathrm{O}_{4}$ and the various ferric oxyhydroxides. This technique is only 
sensitive to the ${ }^{57} \mathrm{Fe}$ nucleus present in the material. For example, the Mössbauer spectrum of the $\mathrm{LDH}\left[\mathrm{Fe}^{\mathrm{II}}-\mathrm{Fe}^{\mathrm{III}}-\mathrm{SO}_{4}\right]$ recorded at $78 \mathrm{~K}$ is shown in figure $5 \mathrm{a}$. It is characterised by a paramagnetic $\mathrm{Fe}^{\mathrm{II}}$ doublet $D_{1}$ with a large quadrupole splitting $\Delta=2.91 \mathrm{~mm} \mathrm{~s}^{-1}$ and another $\mathrm{Fe}^{\mathrm{III}}$ doublet $D_{2}$ with a much smaller quadrupole splitting $\Delta=0.47 \mathrm{~mm} \mathrm{~s}^{-1}$. The relative area of the doublet $D_{2}$ gives directly the value of the $\mathrm{Fe}^{\mathrm{III}}$ molar fraction of the $\mathrm{LDH}$; here $x=34 \%$. The substitution of the divalent or trivalent cations by another element can also be followed indirectly with Mössbauer spectroscopy. For example, the spectrum of the $\mathrm{LDH}\left[\mathrm{Fe}^{\mathrm{II}}-\left\{\mathrm{Fe}^{\mathrm{III},} \mathrm{Al}^{\mathrm{III}}\right\}-\mathrm{SO}_{4}\right]$ with a molar ratio $n\left(\mathrm{Al}^{\mathrm{III}}\right) / n\left(\mathrm{Fe}^{\mathrm{III}}\right)$ of 1 is presented in figure $5 \mathrm{~b}$. As expected, one observes a significant decrease of the relative area of doublet $\mathrm{D}_{1}$ and the apparition of a new ferrous doublet $D_{3}$. The origin of doublet $\mathrm{D}_{2}$ was attributed to $\mathrm{Fe}^{\mathrm{II}}$ species having $\mathrm{Al}^{\mathrm{III}}$ ions as first neighbours (Ruby et al., 2008).

\section{Transformation of iron-based layered double hydroxides}

\subsection{Decomposition in anoxic condition}

Iron-based LDHs may transform under anoxic conditions, particularly in basic solution. Two types of transformation were observed depending on the $\mathrm{pH}$ conditions (Ruby et al., 2003, 2006b). At room temperature, the $\mathrm{LDH}\left[\mathrm{Fe}^{\mathrm{II}}-\mathrm{Fe}^{\mathrm{III}}-\mathrm{SO}_{4}\right]$ decomposes at $\mathrm{pH} \sim 11$ according to the following reaction :

$$
\mathrm{Fe}_{4}{ }_{4} \mathrm{Fe}^{\mathrm{III}}{ }_{2}(\mathrm{OH})_{12} \mathrm{SO}_{4}+2 \mathrm{OH}^{-} \Leftrightarrow \mathrm{Fe}^{\mathrm{II}} \mathrm{Fe}^{\mathrm{III}}{ }_{2} \mathrm{O}_{4}+3 \mathrm{Fe}^{\mathrm{II}}(\mathrm{OH})_{2}+\mathrm{SO}_{4}{ }^{2-}+4 \mathrm{H}_{2} \mathrm{O} \text { (5) }
$$

The $\mathrm{LDH}\left[\mathrm{Fe}^{\mathrm{II}}-\mathrm{Fe}^{\mathrm{III}}-\mathrm{CO}_{3}\right]$ transforms into a carbonated aqueous medium at $\mathrm{pH} \sim 10$ according to the following reaction:

$$
\mathrm{Fe}_{4}{ }_{4} \mathrm{Fe}^{\mathrm{III}}(\mathrm{OH})_{12} \mathrm{CO}_{3}+2 \mathrm{CO}_{3}{ }^{2-}+4 \mathrm{H}^{+} \Leftrightarrow \mathrm{Fe}^{\mathrm{II}} \mathrm{Fe}^{\mathrm{III}}{ }_{2} \mathrm{O}_{4}+3 \mathrm{Fe}^{\mathrm{II}} \mathrm{CO}_{3}+8 \mathrm{H}_{2} \mathrm{O}(6)
$$

The $\mathrm{LDH}\left[\mathrm{Fe}^{\mathrm{II}}-\mathrm{Fe}^{\mathrm{III}}-\mathrm{SO}_{4}\right]$ precipitates generally at a $\mathrm{pH}$ close to 7 both in the coprecipitation and the oxidation experiments and therefore reaction (5) can easily be 
avoided. On the contrary, the $\mathrm{LDH}\left[\mathrm{Fe}^{\mathrm{II}}-\mathrm{Fe}^{\mathrm{III}}-\mathrm{CO}_{3}\right]$ precipitates in alkaline solution in a $\mathrm{pH}$ range situated between 8 and 10 and the partial transformation described in reaction (6) occurs within a few days. The introduction of very small amount of phosphate or silicate anions in the solution prevents completely the decomposition of the LDH (Ruby et al., 2006b). This effect was demonstrated to be due to the adsorption of the phosphate species on the lateral faces of the $\mathrm{LDH}\left[\mathrm{Fe}^{\mathrm{II}}-\mathrm{Fe}^{\mathrm{III}}-\mathrm{CO}_{3}\right]$ crystals (Bocher et al., 2003). This adsorption inhibits the release of the carbonate species from the LDH structure.

\subsection{Oxidation reactions}

\subsubsection{In situ transformation within the solid}

The $\mathrm{LDH}\left[\mathrm{Fe}^{\mathrm{II}}-\mathrm{Fe}^{\mathrm{III}}\right]$ can be oxidised in situ within the solid $\mathrm{LDH}\left[\mathrm{Fe}^{\mathrm{II}}-\mathrm{Fe}^{\mathrm{III}}\right]$ if either a strong oxidant such as $\mathrm{H}_{2} \mathrm{O}_{2}$ is used or if the oxidation is performed in a strongly aerated medium. In these conditions, the redox potential $E_{\mathrm{h}}$ measured in the suspension increases quickly and the oxidation can be achieved in approximately 1 hour (Fig. 6a). If the starting material is the $\mathrm{LDH}\left[\mathrm{Fe}^{\mathrm{II}}-\mathrm{Fe}^{\mathrm{III}}-\mathrm{CO}_{3}\right.$ ), a continuous range of $\mathrm{LDH}$ related compounds with a variable composition of $x$ will form. The general chemical formula of these compounds is $\mathrm{Fe}_{6(1-x)}^{\mathrm{II}} \mathrm{Fe}_{6 x}^{\mathrm{III}} \mathrm{O}_{12} \mathrm{H}_{2(7-3 x)} \mathrm{CO}_{3}$ with $x$ situated in the range [1/3-1] (Génin et al., 2006b). Reflexion Mössbauer spectra of the compounds at $x=0.33$ and $x=0.5$ are presented in Fig. 7 . The two ferrous doublets $D_{1}$ and $D_{2}$ were attributed to $\mathrm{Fe}^{\mathrm{II}}$ species having respectively water molecules and carbonate species in their close neighbourhoods. The apparition of a new doublet $D_{4}$ at $x$ values higher than 0.33 (Fig. 7b) was attributed to $\mathrm{Fe}^{\mathrm{III}}$ species in an octahedral coordination where a partial deprotonation of the Fe-OH bonding occurred. This hypothesis was confirmed by X-ray photoelectron spectroscopy by recording the evolution of the O1s spectrum (Mullet et al.). A progressive decrease of the $\mathrm{OH}^{-}$component is observed when the ratio $x$ increases (Fig 8). This deprotonation process was also supported by the X- 
ray diffraction patterns that exhibit a contraction of a few percentage of the crystallographical cell and a progressive disordering of the structure. The hexagonal morphology of the crystal was shown to be conserved by TEM attesting that the oxidation occurred within the solid. The compound is therefore not longer stricto sensu a layered double hydroxide but rather a oxyhydroxycarbonate that has a crystallographical structure strongly related to the initial $\mathrm{LDH}\left[\mathrm{Fe}^{\mathrm{II}}-\mathrm{Fe}^{\mathrm{III}}-\mathrm{CO}_{3}\right]$ at $x=0.33$.

\subsubsection{Dissolution-precipitation mechanism}

If the kinetics of the aerial oxidation of the $\mathrm{LDH}\left[\mathrm{Fe}^{\mathrm{II}}-\mathrm{Fe}^{\mathrm{III}}\right]$ is slower, the evolution of the redox potential (Fig. 6b) is quite different in comparison with the one observed in figure 6a. Slow oxidation is achieved by introducing a small amount of $\mathrm{O}_{2}$ bubbling into the suspension and the end of oxidation lasts now approximately 7 hours. The curves present initially a small hook followed by two plateaus separated by an equivalent point E. Point E corresponds to the end of the oxidation reaction and its position is shifted on the right of the time scale if the $\mathrm{O}_{2}$ bubbling diminishes (not shown). In carbonated medium, most of the time goethite $\alpha$-FeOOH is the end-product of oxidation. On the contrary to the oxyhydroxycarbonate oxidation product observed in section 3.2.1, the crystallographical structure and morphology of goethite (needles) is quite different if compared to the initial LDH structure. Therefore, the mechanism of formation involved here is rather a dissolution-precipitation process. The presence of the first $E_{\mathrm{h}}$ plateau shows that a redox equilibrium exists between the $\mathrm{LDH}\left[\mathrm{Fe}^{\mathrm{II}}-\mathrm{Fe}^{\mathrm{III}}-\mathrm{CO}_{3}\right]$ and goethite during the quasi-totality of the oxidation process. Therefore a simple measure of the redox potential of the suspension can be used as a guide to know which kind of oxidation mechanism is involved, i.e. in situ oxidation or dissolution-precipitation. 


\section{Conclusion}

Iron-based layered double hydroxides, i.e. the $\operatorname{LDHs}\left[\left\{\mathrm{Fe}^{\mathrm{II}}-\mathrm{M}^{\mathrm{II}}\right\},\left\{\mathrm{Fe}^{\mathrm{III}}-\mathrm{M}^{\mathrm{III}}\right\}\right]$ that contain an iron molar fraction higher than $50 \%$, are synthesised either by the coprecipitation of dissolved cations or by the oxidation of hydroxylated divalent cations. The non-substituted $\mathrm{LDH}\left[\mathrm{Fe}^{\mathrm{II}}-\mathrm{Fe}^{\mathrm{III}}\right]$, commonly called green rust, prepared at room temperature by both methods exhibits well crystallised hexagonal crystals. Partial substitution of the $\mathrm{Fe}^{\mathrm{II}}$ or the $\mathrm{Fe}^{\mathrm{III}}$ species by other cations leads to a rapid decrease of crystal size. The $\mathrm{LDH}\left[\mathrm{Fe}^{\mathrm{II}}-\mathrm{Fe}^{\mathrm{III}}-\mathrm{SO}_{4}\right]$ contains a bi-layer of oriented sulphated anions and water molecules in the interlayer spacing. The $\mathrm{LDH}\left[\mathrm{Fe}^{\mathrm{II}}-\mathrm{Fe}^{\mathrm{III}}-\mathrm{CO}_{3}\right]$ contains only one layer of $\mathrm{CO}_{3}{ }^{2-}$ and water molecules inside the interlayer. Thermal treatments or alkaline conditions $(\mathrm{pH}>9)$ activate the decomposition of iron-based LDHs into biphasic mixtures. Adsorption of small quantity of phosphate or silicate anions on the lateral faces of the crystals slowed down this transformation for the LDH[Fe ${ }^{\mathrm{II}}$ $\left.\mathrm{Fe}^{\mathrm{III}}-\mathrm{CO}_{3}\right]$. In oxic conditions, kinetically fast reactions lead to an in-situ transformation of the LDH that transforms into an oxyhydroxysalt by the deprotonation of hydroxyl groups. On the contrary to most of the other LDHs, iron-based LDHs have a redox flexibility in the range [1/3-1] for the $\mathrm{Fe}^{\mathrm{III}}$ molar fraction $x$. If the kinetics of the oxidation is slower, the LDH transforms into a ferric oxyhydroxide by a dissolution-precipitation mechanism. The structural characterisation of iron-based LDHs has been investigated by several techniques such as high resolution X-ray diffraction, transmission electron microscopy and X-ray photoelectron and Mössbauer spectroscopies. Future works could be devoted to use ironbased LDHs for reducing anionic pollutants in conditions closer to field conditions, e.g. column reactors. Therefore the formation and reactivity of such compounds as coatings at the surface of minerals (e.g. quartz or clays) could be the subject of further studies. 


\section{References}

Aisawa, S., Higashiyama, N., Takahashi, S., Hirahara, H., Ikematsu, D., Kondo, H., Nakayama, H., Narita, E., 2007. Intercalation behavior of 1-ascorbic acid into layered double hydroxides. Appl. Clay Sci. 35, 146-154.

Aïssa, R., Francois, M., Ruby, C., Fauth, F., Medjahdi, G., Abdelmoula, M., Génin J.-M.R., 2006. Formation and crystallographical structure of hydroxysulphate and hydroxycarbonate green rusts synthetised by coprecipitation. J. Phys. Chem. Solids 67, 1016-1019.

Allmann, R., 1968. Crystal structure of pyroaurite. Acta Crystallogr. B Struct. Crystallogr. Cryst. Chem. 24, 972-977.

Bearcock, J.M., Perkins, W.T., Dinelli, E., Wade, S.C., 2006. Fe(II)/Fe(III) 'green rust' developed within ochreous coal mine drainage sediment in South Wales, UK. Mineral. Mag. 70, 731-741.

Bernal, J.D., Dasgupta, D., Mackay, A.L., 1959. The oxides and hydroxides of iron and their structural inter-relationships. Clay Min. Bull. 4, 15-30.

Bond, D.L., Fendorf, S., 2003. Kinetics and structural constraints of chromate reduction by green rusts. Environ. Sci. Technol. 37, 2750-2757.

Bocher, F., Géhin, A., Ruby, C., Ghanbaja, J., Abdelmoula, M., Génin, J.-M.R., 2004. Coprecipitation of $\mathrm{Fe}(\mathrm{II}-\mathrm{III})$ hydroxycarbonate green rust stabilised by phosphate adsorption. Solid State Sci. 6, 117-124.

Christiansen, B.C., Balic-Zunic, T., Dideriksen, K., Stipp, S.L.S., 2009. Identification of green rust in groundwater. Environ. Sci. Technol. 43, 3436-3441.

Clemente-León, M., Coronado, E., Primo, V., Ribera A., Soriano-Portillo, A., 2008. Hybrid magnetic materials formed by ferritin intercalated into a layered double hydroxide. Solid State Sci. 10, 1807-1813. 
De Waal, S.A., Viljoen, E.A., 1971. Nickel minerals from Barberton, South Africa. IV. Reevesite, a member of the hydrotalcite group. Am. Mineral. 56, 1077-81.

Feitknecht, W., Keller G., 1950. Über die dunkelgrünen hydroxyverbindungen des eisens. Z. Anorg. Allg. Chem. 262, 61-68.

Génin J.-M.R., Ruby C., Géhin, A., Refait, P., 2006a. Synthesis of green rusts by oxidation of $\mathrm{Fe}(\mathrm{OH})_{2}$, their products of oxidation and reduction of ferric oxyhydroxides; Eh-pH Pourbaix diagrams. C. R. Geosci. 338, 433-446.

Génin, J.-M.R., Ruby, C., Upadhyay, C., 2006b. Structure and thermodynamics of ferrous, stoichiometric and ferric oxyhydroxycarbonate green rusts; redox flexibility and fougerite mineral. Solid State Sci. 8, 1330-1343.

Hanna, K., Kone ,T., Ruby, C., 2009. Fenton-like oxidation and mineralization of phenol using synthetic $\mathrm{Fe}(\mathrm{II})-\mathrm{Fe}(\mathrm{III})$ green rusts. Environ. Sci. Pollut. Res. In press (DOI 10.1007/s 11356-009-0148-y).

Hansen, H.C.B., Koch, C.B., Taylor, R.M., 1994. Synthesis and characterization of cobalt(II)iron(III) hydroxide carbonate, a layered double hydroxide belonging to the pyroaurite group. J. Solid State Chem. 113, 46-53.

Hansen, H.C.B., 2001. Environmental chemistry of iron(II)-iron(III) LDHs (green rusts), in: Rives, V. (Eds.), Layered double hydroxides: present and future. Nova Science Publishers, Huntington, N.Y., pp. 469-93.

Hansen, H.C.B., Guldberg, S., Erbs, M., Koch, C.B., 2001. Kinetics of nitrate reduction by green rusts-effects of interlayer anion and Fe(II):Fe(III) ratio. Appl. Clay Sci. 18, 81-91.

Hayashi, H., Kanie, K., Shinoda, K., Muramatsu, A., Suzuki, S., Sasaki, H., 2009. pHdependence of selenate removal from liquid phase by reductive $\mathrm{Fe}$ (II)-Fe(III) hydroxysulfate compound, green rust. Chemosphere 76, 638-643. 
Khan, A.I., O'Hare, D., 2002. Intercalation chemistry of layered double hydroxides: recent developments and applications. J. Mater. Chem. 12, 3191-3198.

Kone, T., Hanna, K., Abdelmoula, M., Ruby, C., Carteret C., 2009. Reductive transformation and mineralization of an azo dye by hydroxysulphate green rust preceding oxidation using $\mathrm{H}_{2} \mathrm{O}_{2}$ at neutral $\mathrm{pH}$. Chemosphere 75, 212-219.

Legrand, L., Figuigui, A.E., Mercier, F., Chausse, A., 2004. Reduction of aqueous chromate by $\mathrm{Fe}(\mathrm{II}) / \mathrm{Fe}(\mathrm{III})$ carbonate green rust: kinetic and mechanistic studies. Environ. Sci. Technol. 38, 4587-4595.

Loyaux-Lawniczak, S., Refait, Ph., Ehrhardt, J.-J., Lecomte, P., Génin, J.-M.R., 2000. Trapping of $\mathrm{Cr}$ by formation of ferrihydrite during reduction of chromate ions by $\mathrm{Fe}(\mathrm{II})-$ Fe(III) hydroxysalt green rusts. Environ. Sci. Technol. 34, 438-443.

Ma, R., Liu, Z., Takada, K., Iyi N., Bando, Y., Sasaki, T., 2007. Synthesis and exfoliation of $\mathrm{Co}^{2+}-\mathrm{Fe}^{3+}$ layered double hydroxides: an innovative topochemical approach, J. Am. Chem. Soc. $129,5257-5263$.

Ma, R., Takada, K., Fukuda, K., Iyi, N., Bando, Y., Sasaki, T., 2008. Topochemical synthesis of monometallic $\left(\mathrm{Co}^{2+}-\mathrm{Co}^{3+}\right)$ layered double hydroxide and its exfoliation into positively charged $\mathrm{Co}(\mathrm{OH})_{2}$ nanosheets. Angew. Chem. 120, 92 -95.

Miyata, S., 1983. Anion-exchange properties of hydrotalcite-like compounds. Clays Clay Miner. 31, 305-311.

Mullet, M.; Guillemin, Y.; Ruby, C., 2008. Oxidation and deprotonation of synthetic FeIIFeIII (oxy)hydroxycarbonate Green Rust: An X-ray photoelectron study, J. Solid State Chem., 181, 81-89.

Oh, J.-M., Kwak, S.-Y., Choy, J.-H., 2006. Intracrystalline structure of DNA molecules stabilized in the layered double hydroxide. J. Phys. Chem. Solids 67, 1028-1031. 
Refait, P., Génin, J.-M.R., 1993. The oxidation of nickel(II)-iron(II) hydroxides in chloridecontaining aqueous media. Corros. Sci. 34, 2059-70.

Refait, P., Simon, L., Génin, J.-M.R., 2000. Reduction of $\mathrm{SeO}_{4}{ }^{2-}$ anions and anoxic formation of iron(II)-iron(III) hydroxy-selenate green rust. Environ. Sci. Technol. 34, 819-825.

Refait, P., Abdelmoula, M., Trolard, F., Génin, J.-M.R., Bourrié, G., 2001. Mössbauer and XAS study of a green rust mineral; the partial substitution of $\mathrm{Fe}^{2+}$ by $\mathrm{Mg}^{2+}$. Am. Mineral. $86,731-739$.

Refait, Philippe; Abdelmoula, Mustapha; Simon, Lilian; Genin, Jean-Marie R. 2005a, Mechanisms of formation and transformation of Ni-Fe layered double hydroxides in $\mathrm{SO}_{3}{ }^{2-}$ and $\mathrm{SO}_{4}{ }^{2-}$ containing aqueous solutions. J. Phys. Chem. of Solids 66, 911-917.

Refait, Ph.; Drissi, S. H.; Abdelmoula, M.; Jeannin, M.; Reffass, M.; Genin, J.-M. R., 2005b Mechanisms of formation and transformation of $\mathrm{Ni}-\mathrm{Fe}$ hydroxycarbonates. AIP Conference Proceedings, 765 (Industrial Applications of the Mössbauer Effect), 79-84.

Ruby, C., Géhin, A., Abdelmoula M., Génin, J.-M.R., Jolivet, J.-P., 2003. Coprecipitation of $\mathrm{Fe}(\mathrm{II})$ and $\mathrm{Fe}(\mathrm{III})$ cations in sulphated aqueous medium and formation of hydroxysulphate green rust. Solid State Sci. 5, 1055-1062.

Ruby, C., Géhin, A., Aïssa, R., Génin, J.-M.R. 2006a. Mass-balance and $\mathrm{E}_{\mathrm{h}}-\mathrm{pH}$ diagrams of $\mathrm{Fe}^{\mathrm{II}}{ }^{\mathrm{III}}$ green rust in aqueous sulphated solution, Corrosion Sci., 48, 3824-3837.

Ruby, C., Aïssa, R., Géhin, A., Cortot, J., Abdelmoula, M., Génin, J.-M.R., 2006b. Green rusts synthesis by coprecipitation of $\mathrm{Fe}^{\mathrm{II}}-\mathrm{Fe}^{\mathrm{III}}$ ions and mass-balance diagram. C. R. Geosci. 338, 420-432.

Ruby, C., Géhin, A., Aïssa, R., Ghanbaja, J., Abdelmoula, M., Genin, J.-M.R., 2007. Chemical stability of hydroxysulphate green rust synthesized in the presence of foreign anions: carbonate, phosphate and silicate. Hyperfine Inter. 167, 803-807. 
Ruby, C., Abdelmoula, M., Aïssa, R., Medjahdi, G., Brunelli, M., François, M., 2008. Aluminium substitution in iron(II-III)-layered double hydroxides: Formation and cationic order. J. Solid State Chem. 181, 2285-2291.

Stampfl, P.P., 1969. Ein basiches eisen-II-III-karbonat in rost. Corrosion Sci. 9, 185-187.

Tamaura, Y.,1985. Ferrite formation from the intermediate, green rust II, in the transformation reaction of ferric hydroxide oxide, $\gamma-\mathrm{FeO}(\mathrm{OH})$, in aqueous suspension. Inorg. Chem. 24, 4363-4366.

Trolard, F., Génin, J.-M.R., Abdelmoula, M., Bourrié, G., Humbert, B., Herbillon, A., 1997. Identification of a green rust mineral in a reductomorphic soil by Mossbauer and Raman spectroscopies. Geochim. Cosmochim. Acta 61, 1107-1111.

Vial S., Prevot V., Leroux F., Forano C., 2008. Immobilization of urease in ZnAl Layered Double Hydroxides by soft chemistry routes. Micropor. Mesopor. Mat. 107, 190-201.

\section{Figure captions}

Fig. 1 : $\mathrm{M}^{\mathrm{II}}-\mathrm{M}^{\mathrm{III}}$ mass-balance diagram showing the coprecipitation and oxidation synthesis routes.

Fig. 2 : Ternary mass-balance diagrams showing the domains and syntheses routes of $M^{\mathrm{III}}$ (a) and $\mathrm{M}^{\mathrm{II}}$ (b) substituted iron-based LDHs.

Fig. 3 : Morphologies of iron-based LDHs crystals observed by transmission electron microscopy.

Fig. 4 : High resolution X-ray diffraction patterns of hydroxysulphate recorded for a wavelength of the incident beam $\lambda=0.35015 \AA$ (a) and hydroxycarbonate with $\lambda=0.410792 \AA(b)$. 
Fig. 5 : Transmission Mössbauer spectra of hydroxysulphate (a) and $\mathrm{Al}^{\mathrm{III}}$-substituted hydroxysulphate (b).

Fig. 6 : Evolution of the redox potential measured inside the LDHs suspension during aerial oxidation of the iron-based LDHs.

Fig 7 : Backscattered Mössbauer spectra of the hydroxycarbonate (a) and oxyhydroxicarbonate (b).

Fig 8 : O1s XPS spectra of the hydroxycarbonate (a) and oxyhydroxycarbonate (b,c \&d). 
Figure 1

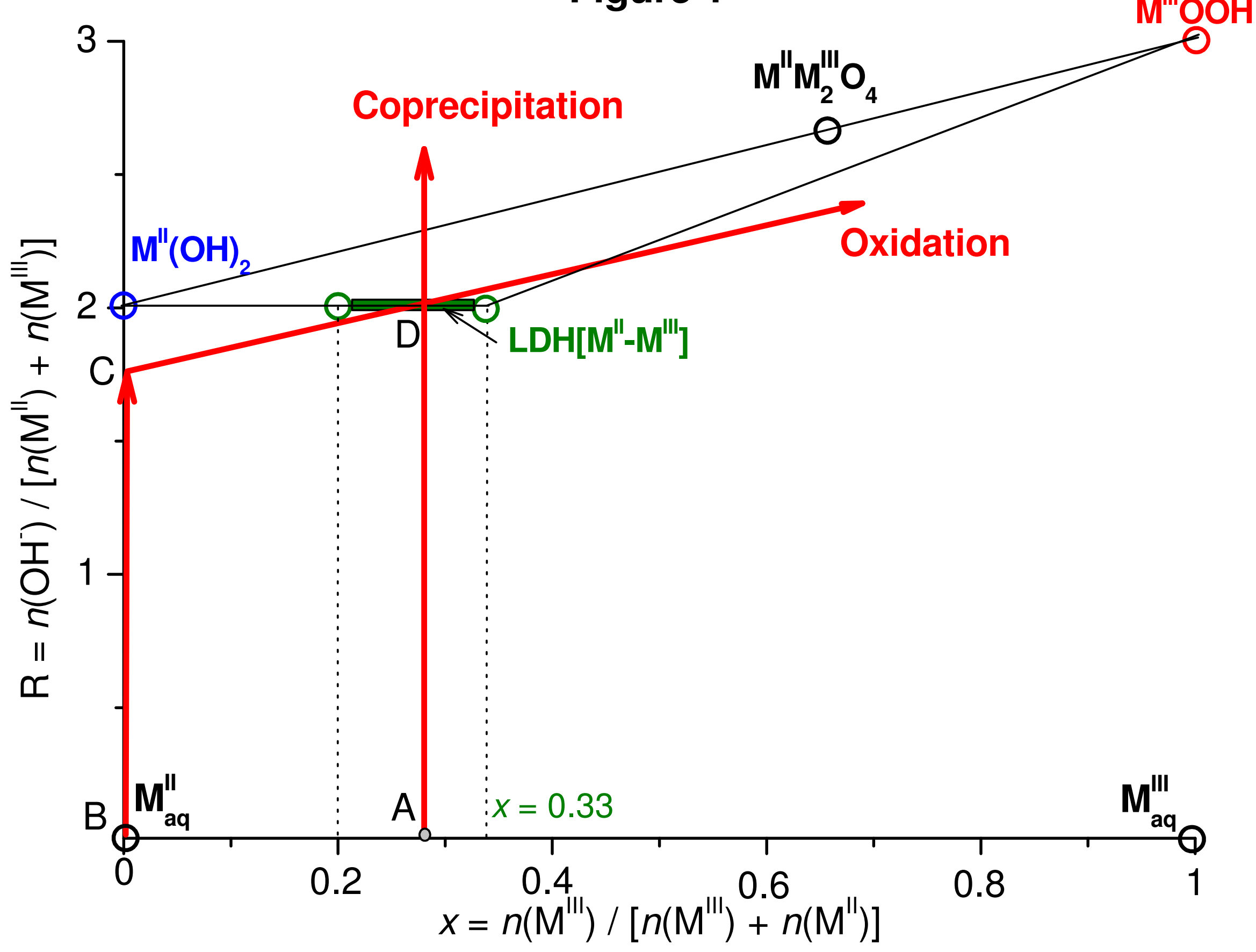


Figure 2

(a)

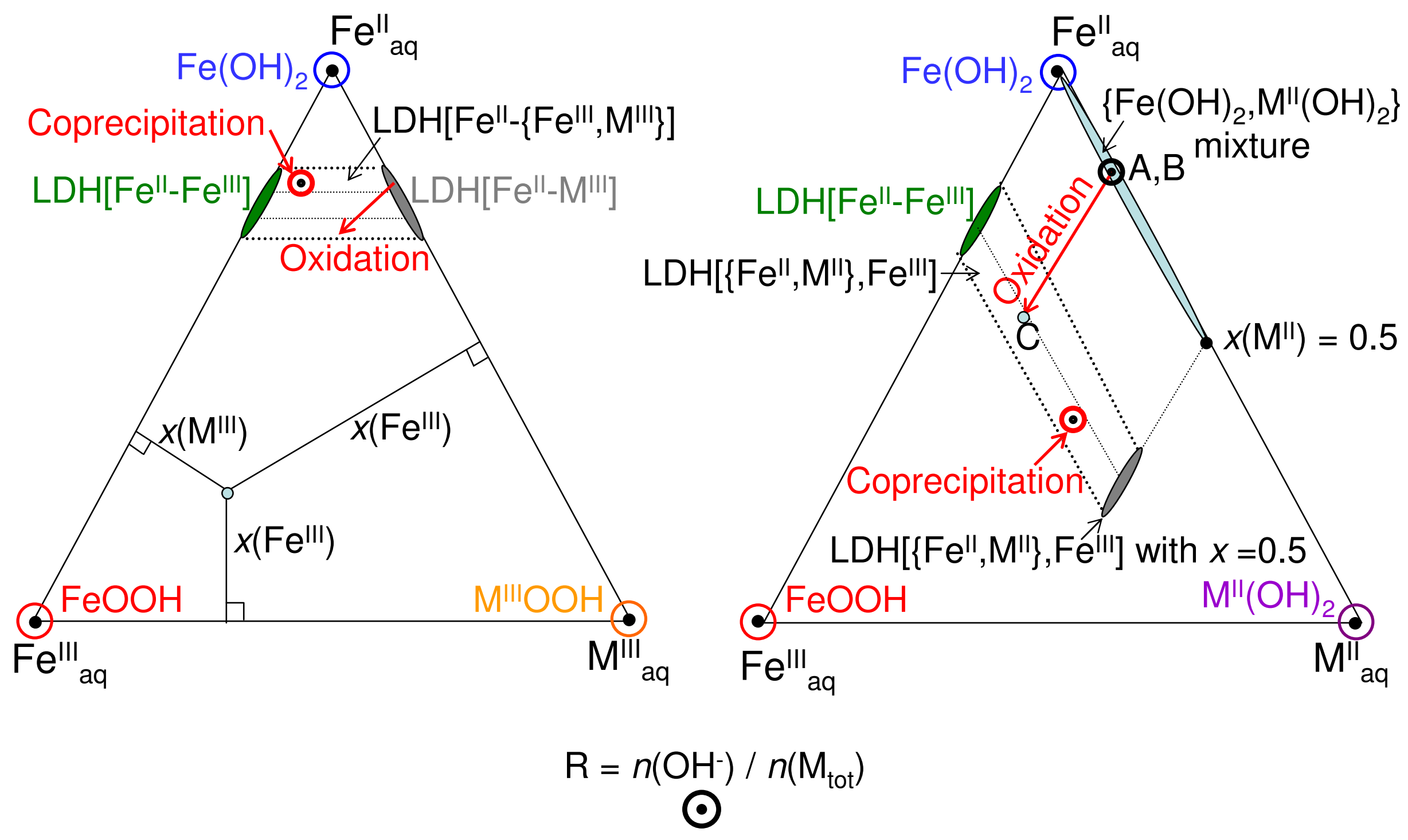

(b) 
Figure 3

\section{(a) LDH [Fe"l-Fe"l']}

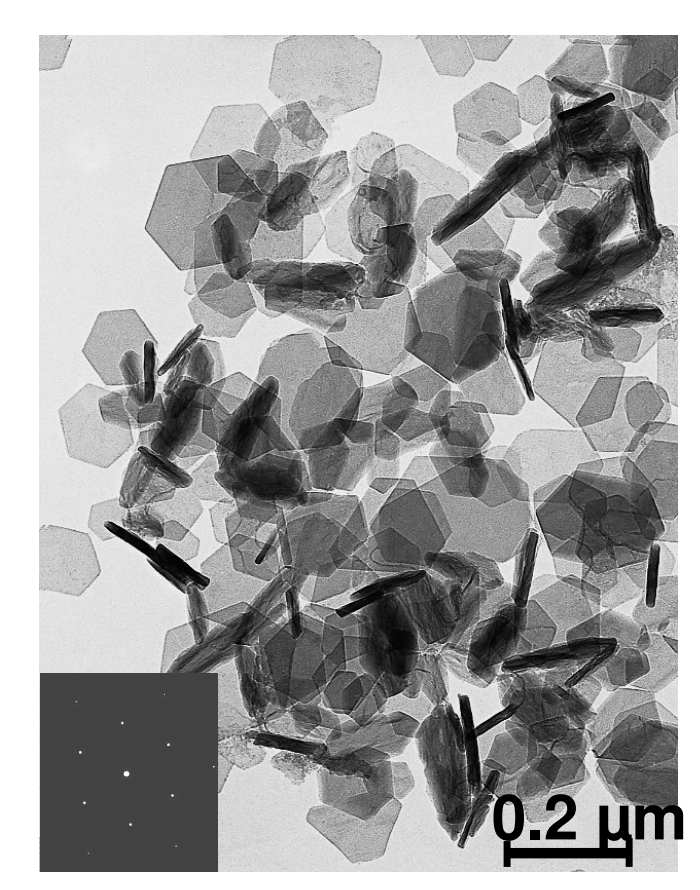

(b) LDH $\left[F e^{\prime \prime}-\left\{F e^{I I I}, A I^{\prime \prime \prime}\right\}\right]$

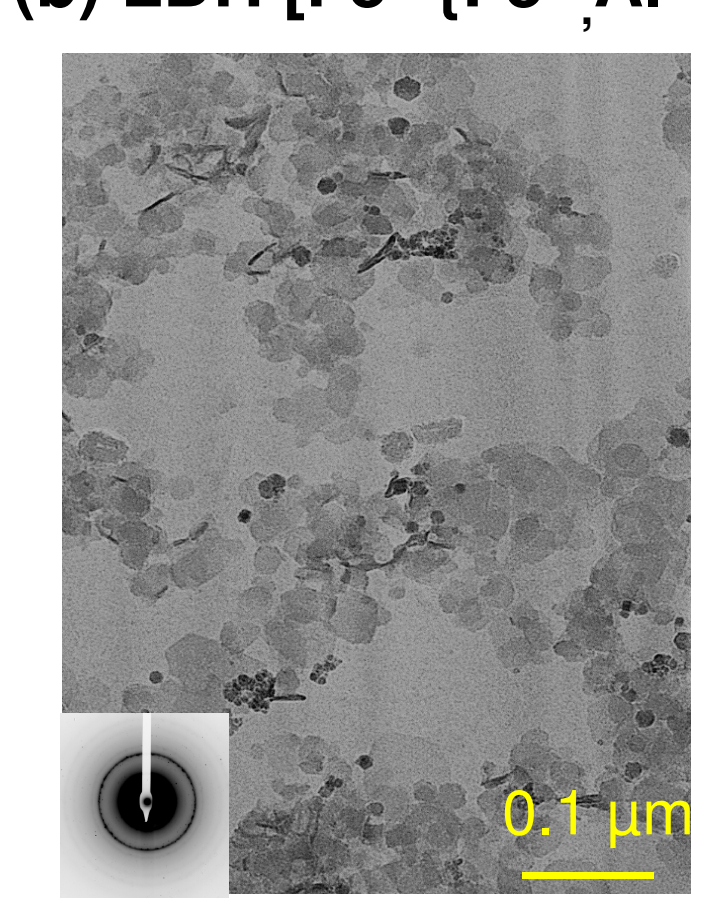

(c) LDH [Nill-Fe $\left.{ }^{I I I}\right]$

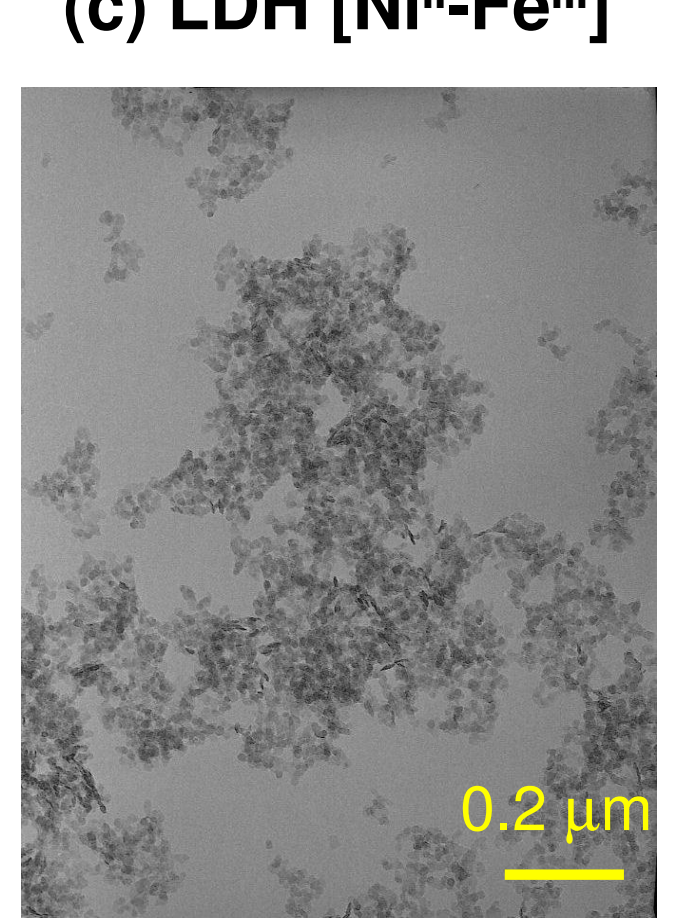


Figure 5
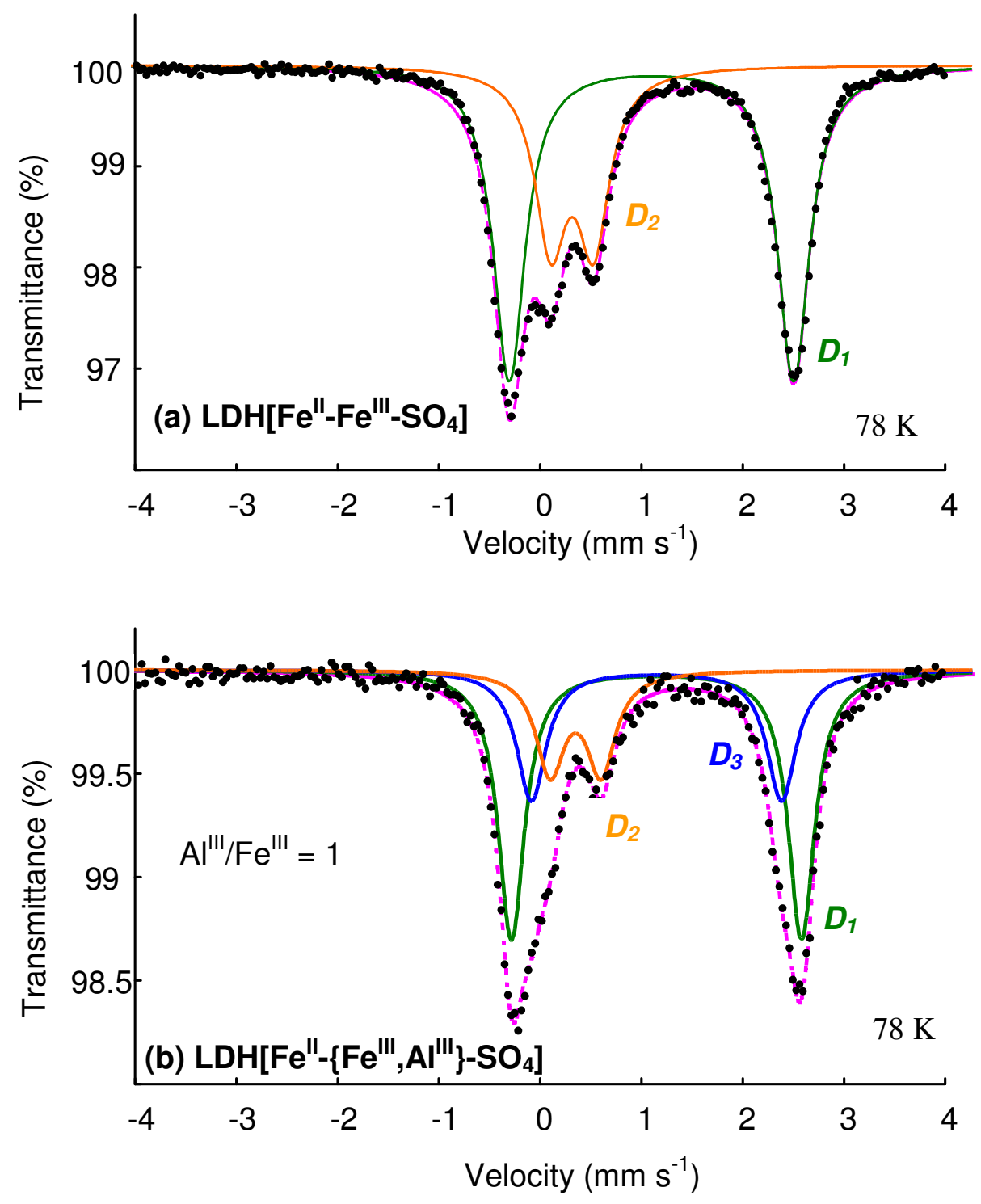
Figure 6
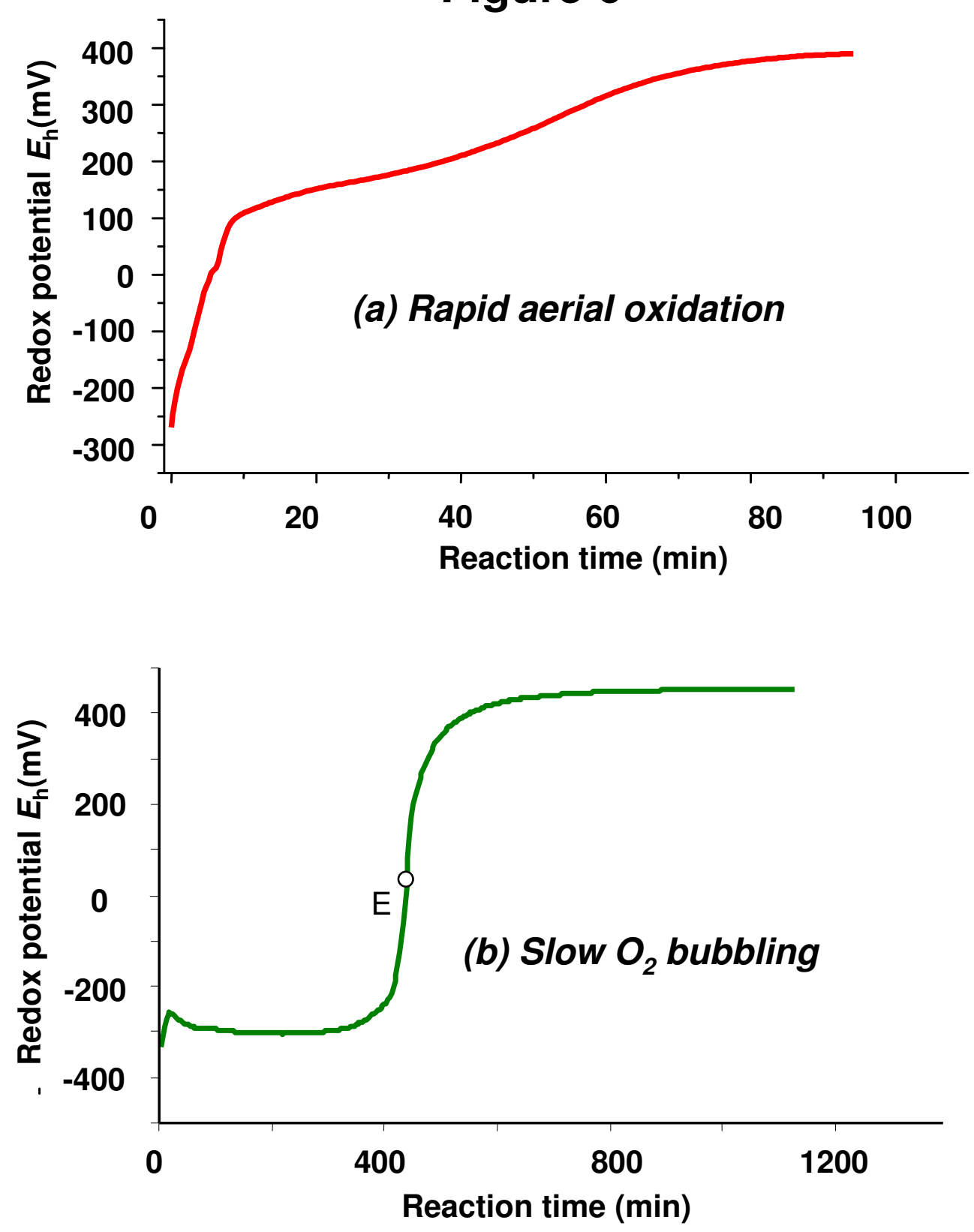
Figure 7
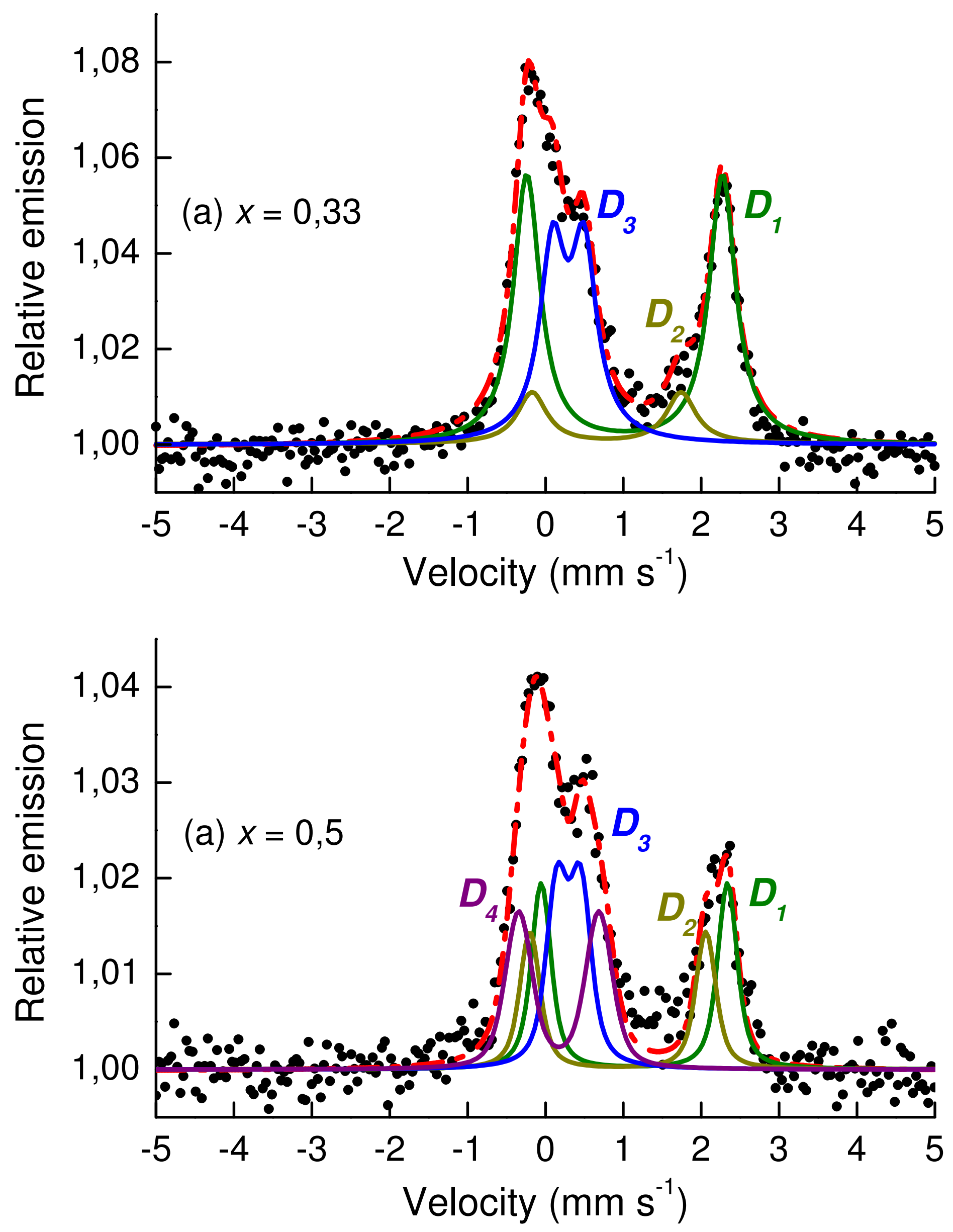
Figure 8
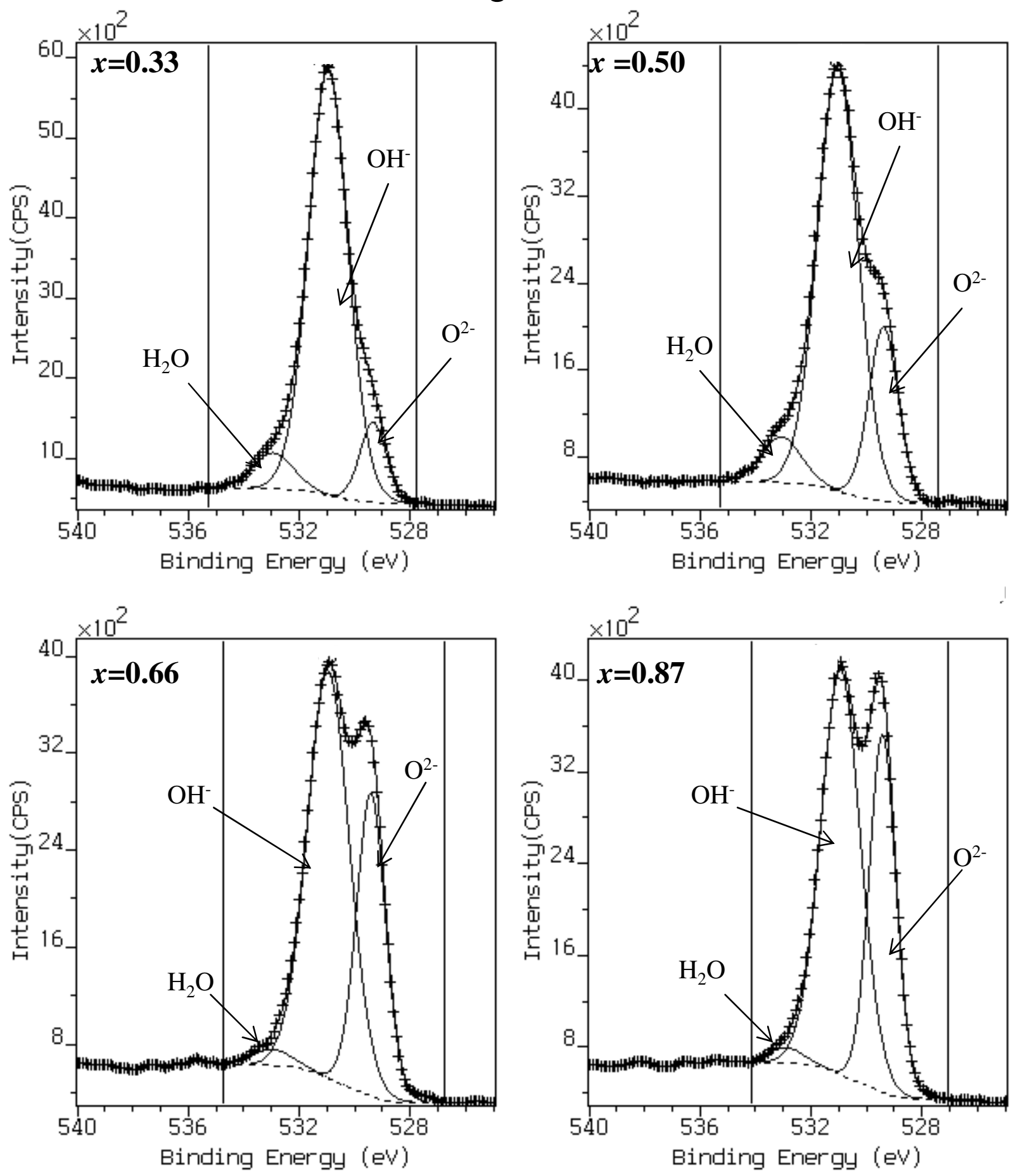